\title{
Effects of omega 3 on doxorubicin-induced cardiotoxicity in an experimental rabbit
}

\section{model}

\author{
Efeitos do ômega 3 na cardiotoxicidade induzida por doxorrubicina em modelo experimental com \\ coelhos
}

Efectos del omega 3 sobre la cardiotoxicidad inducida por doxorrubicina en un modelo

experimental en conejos

Received: 09/23/2021 | Reviewed: 09/30/2021 | Accept: 10/02/2021| Published: 10/04/2021

\author{
Jéssica Cristina de Barros \\ ORCID: https://orcid.org/0000-0003-2009-7121 \\ Universidade de Franca, Brasil \\ E-mail: jessica.cbarros@yahoo.com.br \\ Amanda Garcia Pereira \\ ORCID: https://orcid.org/0000-0002-0816-2798 \\ Universidade de Franca, Brasil \\ E-mail: dinha2608@hotmail.com \\ Marcela Aldrovani Rodrigues \\ ORCID: https://orcid.org/0000-0002-5734-3042 \\ Universidade de Franca, Brasil \\ E-mail: marcela.rodrigues@unifran.edu.br \\ Daniel Paulino Junior \\ ORCID: https://orcid.org/0000-0002-1375-8369 \\ Universidade de Franca, Brasil \\ E-mail: daniel.junior@unifran.edu.br
}

\begin{abstract}
To evaluate the effects of the use of omega 3 at different doses, following the response through stereological and morphometric evaluations in doxorubicin-induced acute cardiotoxicity in an experimental rabbit model. Thirty healthy adult New Zealand rabbits were divided into six groups with different doses of omega 3 treatment, GT125, GT500 and GT 2000, receiving doses of $125 \mathrm{mg} / \mathrm{kg}, 500 \mathrm{mg} / \mathrm{kg}$ and $2000 \mathrm{mg} / \mathrm{kg}$, respectively. The induction of acute cardiotoxicity with doxorubicin was treated for six days prior to intravenous administration of $10 \mathrm{mg} / \mathrm{kg}$ single dose. Then, the animals were euthanized and myocardial samples were collected for stereological and morphometric evaluations. The stereological evaluation showed an increase in the transverse area of cardiomocytes between the SHAM and GT2000 groups and an increase in the interstitial collagen volume density between the SHAM and GT500 and SHAM and GT2000 groups. The omega $3500 \mathrm{mg} / \mathrm{kg}$ dose has the potential to attenuate the fibrotic effects of doxorubicin use and the use of a single dose of $10 \mathrm{mg} / \mathrm{kg}$ doxorubicin can be used as an acute dilated cardiomyopathy induction protocol in an experimental model using rabbits.
\end{abstract}

Keywords: Omega 3; Cardiotoxicity; Doxorubicin.

\section{Resumo}

Avaliar os efeitos do uso do ômega 3 em diferentes doses, acompanhando a resposta através de avaliações estereológicas e morfométricas na cardiotoxicidade aguda induzida por doxorrubicina em modelo experimental com coelhos. Trinta coelhos adultos hígidos da raça nova Zelândia foram distribuídos em seis grupos com diferentes doses de tratamento com ômega 3 sendo $\mathrm{GT}_{125}, \mathrm{GT}_{500}$ e GT 2000 , recebendo as doses de $125 \mathrm{mg} / \mathrm{kg}, 500 \mathrm{mg} / \mathrm{kg}$ e $2000 \mathrm{mg} / \mathrm{kg}$, respectivamente. Foram tratados durante seis dias prévios a indução da cardiotoxicidade aguda com doxorrubicina, utilizando a dose de $10 \mathrm{mg} / \mathrm{kg}$ intravenosa em aplicação única. Ato contínuo, os animais foram eutanasiados e amostras do miocárdio foram coletadas para avaliações estereológicas e morfométricas. A avaliação estereológica evidenciou aumento na área transversa de cardiomócitos entre os grupos SHAM e $\mathrm{GT}_{2000}$ e aumento na densidade de volume de colágeno intersticial ente os grupos SHAM e GT G00 $_{5}$ SHAM e GT $_{2000}$. A dose de 500mg/kg de ômega 3 apresentou potencial para atenuar os efeitos fibróticos do uso da doxorrubicina e a utilização da dose de $10 \mathrm{mg} / \mathrm{kg}$ de doxorrubicina em dose única pode ser utilizada como protocolo de indução de cardiomiopatia dilatada aguda em modelo experimental utilizando coelhos.

Palavras-chave: Ômega 3; Cardiotoxicidade; Doxorrubicina. 


\section{Resumen}

Evaluar los efectos del uso del omega en diferentes dosis, monitoreando la respuesta a través de evaluaciones estereológicas y morfométricas en la cardiotoxicidad aguda inducida por doxorrubicina en un modelo experimental con conejos. Treinta conejos adultos saludables de la raza nueva Zelandia fueron distribuidos en seis grupos con diferentes dosis de tratamiento con omega \# siento $\mathrm{GT}_{125}, \mathrm{GT}_{500}$ y $\mathrm{GT}$ 2000, recibiendo las dosis de $125 \mathrm{mg} / \mathrm{kg}$, 500 $\mathrm{mg} / \mathrm{kg}$ y $2000 \mathrm{mg} / \mathrm{kg}$, respectivamente. Se trataron seis días antes a la inducción de cardiotoxicidad aguda con doxorrubicina, utilizando la dosis de $10 \mathrm{mg} / \mathrm{kg}$ intravenosa en aplicación única. Los animales se sacrificaron continuamente y se recolectaron muestras de miocardio para evaluaciones estereológicas y morfométricas. La evaluación estereológica mostró un aumento en el área transversal de cardiomocitos entre los grupos $\mathrm{SHAM}_{\mathrm{H}} \mathrm{GT}_{2000}$ y aumento en la densidad de volumen del colágeno intersticial entre los grupos SHAM y GT 500 y SHAM y GT 2000 . La dosis de $500 \mathrm{mg} / \mathrm{kg}$ de omega 3 presentó potencial para atenuar los efectos de fibrosis con el uso de la doxorrubicina y la utilización de la dosis de $10 \mathrm{~m} / \mathrm{kg}$ de doxorrubicina en dosis única puede ser utilizada como protocolo de inducción de cardiomiopatía dilatada aguda en un modelo experimental usando conejos.

Palabras clave: Omega 3; Cardiotoxicidad; Doxorrubicina.

\section{Introduction}

Doxorubicin is a chemotherapy agent widely used in the oncology routine in humans, and no different in veterinary medicine. It is an anthracycline drug, indicated for the treatment of hematologic neoplasms, carcinomas, primary lung tumors, among others (Luu et al. 2018, Olson et al. 1978).

With the advancement of clinical specialties, oncology is the area that receives great attention in the development of new diagnostic and therapeutic techniques favoring that children have a survival rate of $70 \%$ after tumor diagnosis. To achieve this success, the essential drug in the therapeutic protocol is doxorubicin, but long-term toxicity is the main concern for maintaining patients' quality of life (Curry et al. 2006).

Among the adverse effects, cardiotoxicity is a limiting factor for the prognosis of patients who use the drug. Injury to cardiomyocytes occurs due to non-selectivity of the chemotherapeutic agent to cancer cells (Luu et al. 2018, Curry et al. 2006).

Several mechanisms are related to causing early myocardial damage, including free radical release and lipid peroxidation (Gewirtz D. 1999).

Initially, dilated cardiomyopathy secondary to the use of anthracyclines is asymptomatic, requiring additional resources such as imaging studies that may show cardiac structural abnormalities, and later evolving to congestive heart failure with specific clinical signs (Oeffinger et al. 2006, Kero et al. al. 2014)

Research around the world seeks therapeutic options that minimize the harmful effects of doxorubicin, promoting increased survival in patients undergoing anthracycline (Hardman WE. 2004).

Long chain fatty acids or popularly known as omega 3 have numerous beneficial actions to the body when used at the correct doses and frequencies. Emerging studies demonstrate the ability of omega 3 to enhance antitumor efficacy when used in adjuvant chemotherapy such as anthracyclines, carboplatin, gemcitabine, among others (Hardman WE. 2004, Murphy et al. 2011). Corroborating these data, the action of omega 3 in rats submitted to doxorubicin and supplemented with omega 3 resulted in cardioprotective and chemosensitizing action (Xue et al. 2016).

This study aimed to evaluate the cardioprotective effects of the use of omega 3 at different doses, following the response in electrocardiographic evaluations and through stereological and morphometric analyzes in acute cardiotoxicity in an experimental model with rabbits. Still, the study aims to analyze the dose of $10 \mathrm{mg} / \mathrm{kg}$ in a single application of doxorubicin for induction of acute dilated cardiomyopathy in cleft species. 


\section{Methodology}

\section{Ethical approval and study groups}

The study with applied research methodology, under the supervision of the professors of the postgraduate program, was approved by the Ethics Committee on Animal Use (CEUA) of the University of Franca (UNIFRAN) under protocol No. 9725071117. The experiment was conducted according to the ethical principles established by the Brazilian College of Animal Experimentation (COBEA).

Thirty healthy adult New Zealand rabbits weighing between 2.0 and $4.0 \mathrm{~kg}$ (Anilab - Laboratory Animals, Paulínia, São Paulo) were used. The animals were placed in individual cages, with commercial feed for the species and water provided at will.

The controlled temperature was maintained at $23^{\circ} \mathrm{C}$ with a $12 \mathrm{~h}$ light-dark cycle and controlled humidity in an environment free of external noise. Animals were randomly assigned to 6 groups $(n=5)$ (Table 1$)$.

Table 1. Distribution of rabbits in control and omega 3 treated groups on doxorubicin-induced cardiotoxicity.

\begin{tabular}{lll}
\hline GROUP & $\mathbf{N}^{*}$ & TREATMENT \\
\hline DOX & 5 & Doxorubicin + placebo $(0.9 \%$ saline solution $)$ \\
SHAM & 5 & No doxorubicin + placebo $(0.9 \%$ saline $)$ \\
OM & 5 & Without doxorubicin + omega $3(2000 \mathrm{mg} / \mathrm{kg})$ \\
$\mathrm{GT}_{125}$ & 5 & Doxorubicin + omega $3(125 \mathrm{mg} / \mathrm{kg})$ \\
GT $_{500}$ & 5 & Doxorubicin + omega $3(500 \mathrm{mg} / \mathrm{kg})$ \\
GT $_{2000}$ & 5 & Doxorubicin + omega $3(2000 \mathrm{mg} / \mathrm{kg})$ \\
\hline
\end{tabular}

* N - number of animals per group. $\quad$ SHAM: negative control group. Source: Authors.

\section{Omega 3 protocol for prevention of doxorubicin-induced cardiotoxicity}

The administration of omega 3 (Distriol Industria e Comercio Ltda, Bom Jesus dos Perdões, Brazil) was double-blind, ie the daily suppliers of the medication were not aware of the product offered. Only one collaborator responsible for the draw of the animals and groups belonging was aware of the omega or placebo presentation. All syringes were identified only with the number of the animal being administered orally by gavage every 24 hours for six days in Figure 1

Figure 1. Protocol for administration of omega or placebo and study design

\section{Illustrative methodological timeline}

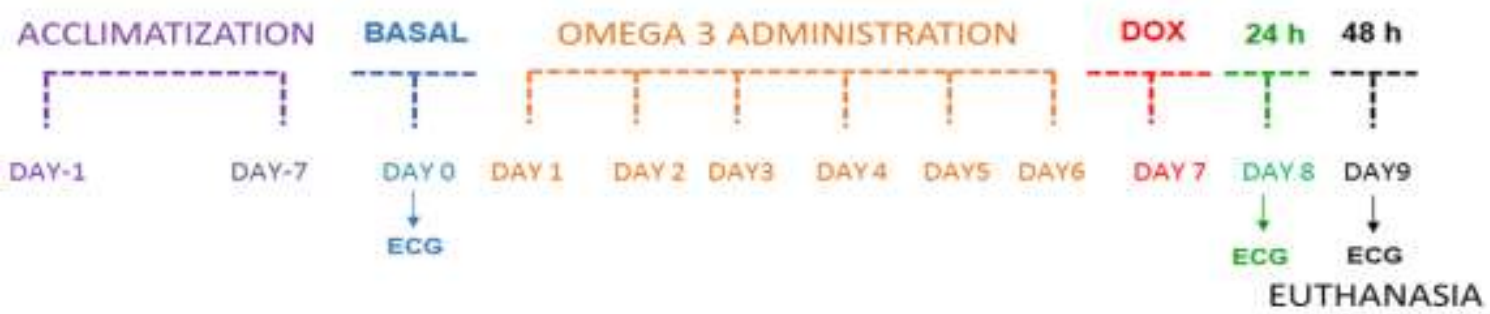

Source: Authors. 
In addition, the SHAM and DOX groups receiving placebo (0.9\% saline solution (JP Farma, Ribeirão Preto, Brazil)) assessed the influence of oral administration (stress effect) every 24 hours during the six days of the study.

\section{Acute doxorubicin cardiotoxicity induction protocol in rabbits}

In previous studies to assess chronic cardiotoxicity, the dose used was $1 \mathrm{mg} / \mathrm{kg}$ intravenous doxorubicin twice a week for 6 weeks totaling 12 applications (Gava et al. 2013). In order to achieve the goal of acute cardiotoxicity induction, in the present study the dose used was $10 \mathrm{mg} / \mathrm{kg}$ in single intravenous application through the cephalic vein. The dose was adapted from studies conducted on acute rat toxicity, taking into account the sensitivity of the cleft species to anthracycline (Chen et al. 2010).

The chemotherapeutic agent (Eurofarma, São Paulo, Brazil) was diluted in 0.9\% saline solution (JP Farma, Ribeirão Preto, Brazil) until it reached a concentration of $2 \mathrm{mg} / \mathrm{ml}$. venous access using a 22 catheter in the cephalic vein after six days of oral omega 3 administration. No animals were submitted to sedation, only physical restraint was recommended. Animals from the SHAM and OM groups that did not receive the doxorubicin bolus received placebo - 0.9\% saline solution (JP Farma, Ribeirão Preto, Brazil), using the same route described above.

\section{Material collection and sample preparation}

The animals were euthanized according to CFMV Resolution 1000, of May 11, 2012, 48 hours after doxorubicin application. Initially, the animal was induced with propofol (Cristália Pharmaceutical Industry, São Paulo, Brazil), followed by potassium chloride 19.1\% (Equiplex Pharmaceutical Industry, Aparecida de Goiânia, Brazil), both intravenously from all groups.

Then, myocardial tissue was collected for further sample processing, from a longitudinal incision in the thoracic region using a scalpel blade 14 (Solidor, Joinvile, Brazil). Immediately after excision, hearts were washed with $0.9 \% \mathrm{NaCl}$ physiological solution (JP Farma, Ribeirão Preto, Brazil). The hearts were incised from the base to the apex, allowing macroscopic evaluation of the cardiac chambers and tissue collection by the Orthotrip method (Pereira et al. 1998), prioritizing two left ventricular myocardial fragments, transverse and longitudinal section, and subsequently fixed. in $10 \%$ buffered formaldehyde solution (Dinamica, Sao Paulo, Brazil).

\section{Stereological analysis and morphometry of the ventricular myocardium}

With the samples properly fixed, they were dehydrated in growing ethanol solutions (Synth, São Paulo, Brazil) and embedded in paraffin (Labsynth, Diadema, Brazil) for microtomy ( $3 \mu \mathrm{m}$ thick sections).

Paraffin heart sections $(3 \mu \mathrm{m})$ were deparaffinized in xylol (Synth, Sao Paulo, Brazil), hydrated in decreasing ethanol (Synth, Sao Paulo, Brazil) and water, and stained with Hematoxylin-Eosin (HE). (Sigma-Aldrich, St. Louis, MO, USA) or Masson (TM) trichrome (Sigma-Aldrich, St. Louis, MO, USA). The samples were examined under a light microscope (Olympus BX53, Tokyo, Japan). With the help of a high resolution color camcorder, images were captured, digitized and analyzed using Stepanizer software (version beta 2.28). The ventricles were evaluated for cardiac fiber volume density, cardiomyocyte transverse area, interstitial collagen volume density and vessel number. A single examiner conducted all evaluations blindly. The test system used for stereological evaluation was 144 points.

Volume density of cardiac fibers and transverse areas of cardiomyocytes, a parameter of muscle hypertrophy, were studied in HE stained samples (14). The volume density of cardiac fibers was calculated using the formula VV = PP / PT, where PP corresponds to the number of points that touch the contractile element and PT corresponds to the number of points 
that make up the test system. The transverse area of cardiomyocytes, in $\mu \mathrm{m} 2$, was calculated with the formula $\mathrm{A}=\mathrm{VV} / 2 \mathrm{x}$ QA, where Vv corresponds to the volumetric density of cardiac fibers and QA represents the number of nuclei within the evaluated microscopic field. Cells that touched the edges of the test system were not counted.

The volume density of interstitial collagen fibers was studied in Masson's trichrome stained samples using the same formula used to evaluate the volume density of cardiac fibers.

Vessel numbers were established by software-assisted morphometry and vessel counts were performed by quadrants in 6 random microscopic fields on each slide. Three slides were studied per animal.

Data analysis

Continuous variables were tested for statistical normality and evaluated by Kruskal Wallis test, one-way ANOVA and ANOVA for repeated measures with Tukey post hoc test. Differences with $\mathrm{P}<0.05$ were considered significant. All calculations and comparisons were performed using the Minitab software program (San Diego, CA, USA).

\section{Results}

\section{Mortality}

The mortality rate was calculated only in GT125 where $100 \%$ of the animals included in the group died, making it impossible to evaluate after 48 hours of doxorubicin induction. This finding represents approximately $17 \%$ mortality in every study.

\section{Stereological and morphometric parameters}

The volume density of cardiac fibers did not change in the six groups evaluated in the Figure 2. 
Figure 2. Representative graph of cardiac fiber density assessment (\%) in rabbits with doxorubicin-induced cardiotoxicity.

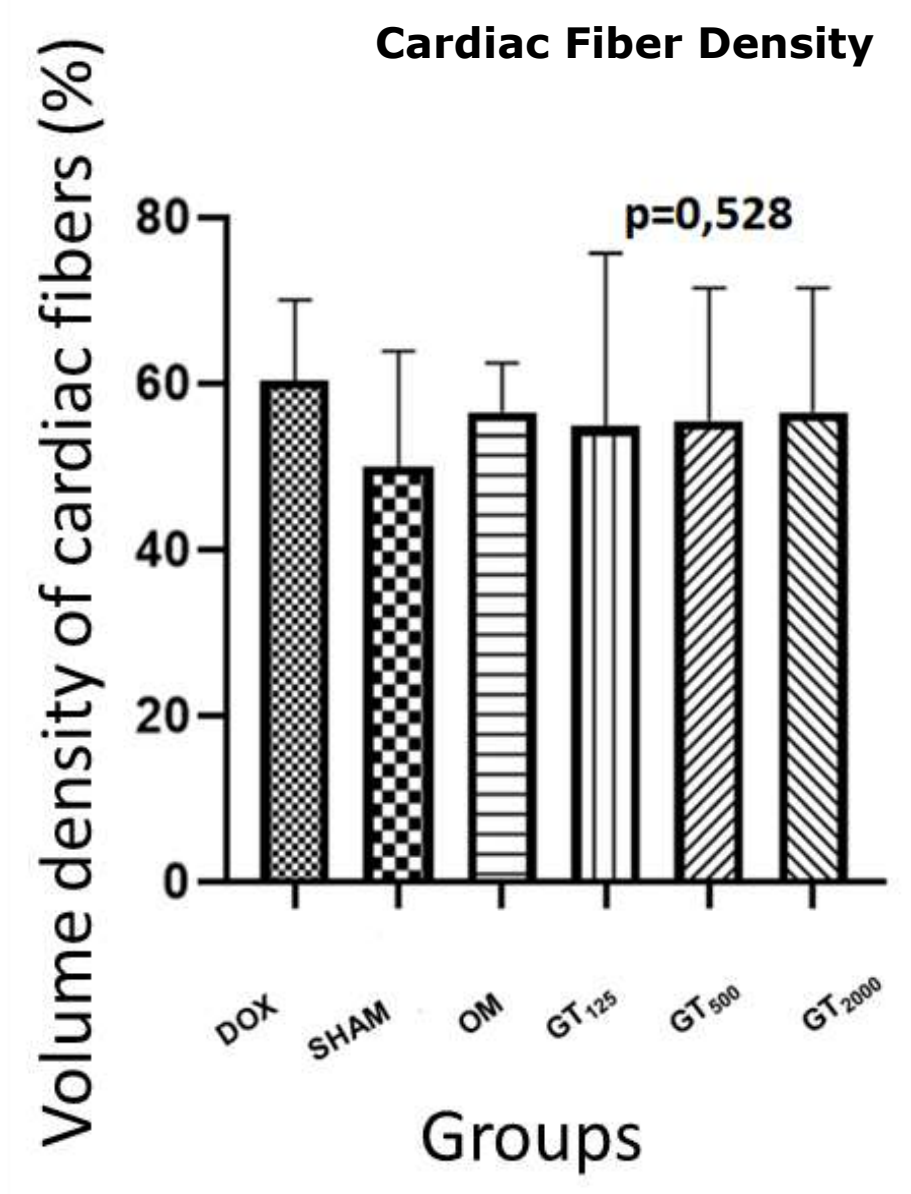

Source: Authors.

After assessing the transverse area of cardiomyocytes, it was noted that there was a statistical difference between the SHAM and GT2000 groups in Figure 3. 
Figure 3. (A) - Photomicrograph of transverse histopathological evaluation of the ventricular myocardium in a 40x objective in a rabbit belonging to the SHAM group. Cell nucleus (arrow), cardiomyocyte (arrowhead) and interstitium (asterisk). Coloring: HE. (B) - Photomicrograph of transverse histopathological evaluation of the ventricular myocardium in a 40x rabbit lens belonging to the GT2000 group. Coloring: HE. (C) - Representative graph of cardiomyocyte cross-sectional area showing the difference between SHAM and GT2000 groups in rabbits with doxorubicin-induced cardiotoxicity $(\mathrm{P}<0.05)$.

\section{Histopathology ventricular myocardium}

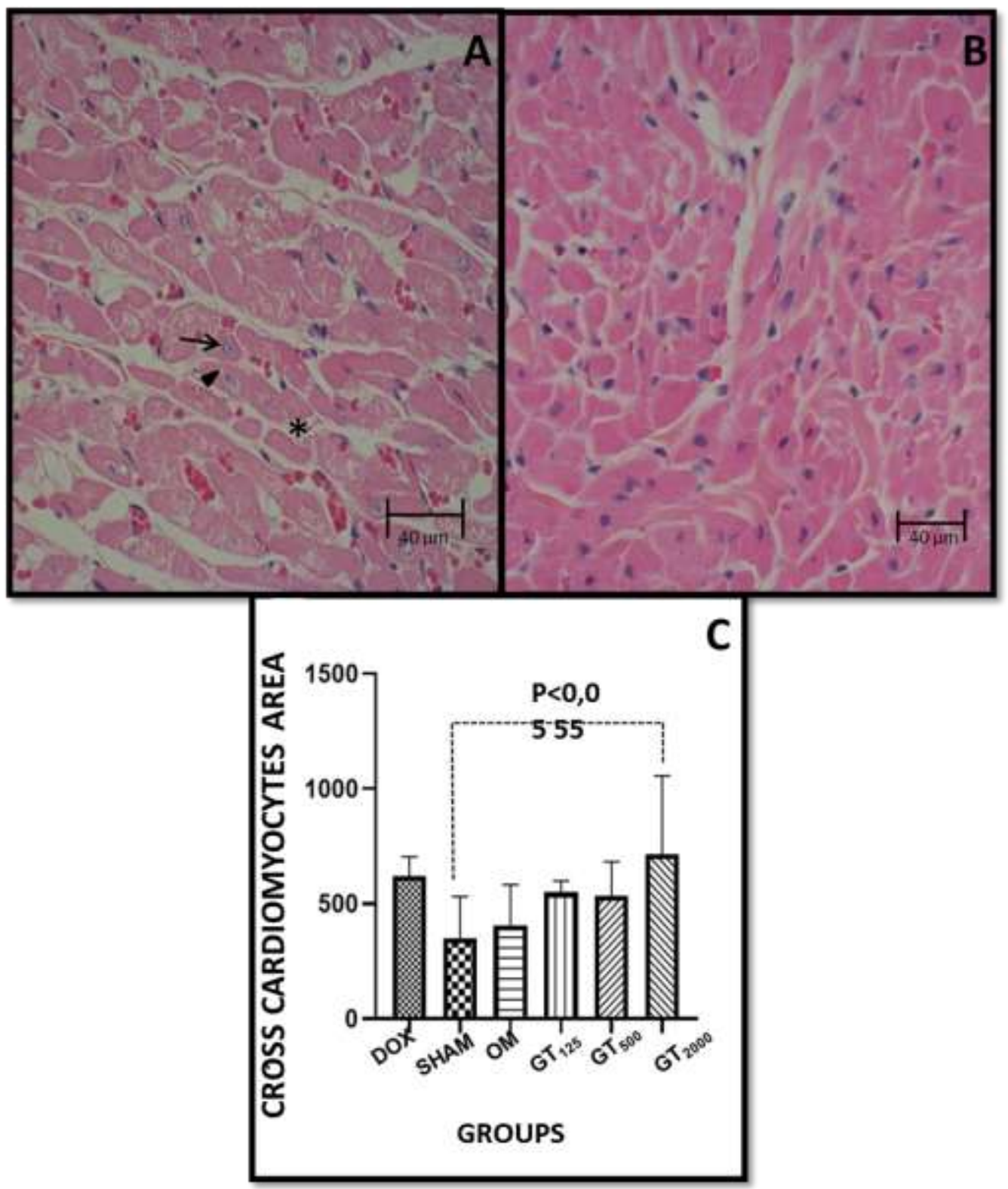

Source: Authors.

Another variable that presented difference between the groups was the interstitial collagen volume density, with statistical difference in the SHAM, GT125 and GT2000 groups in Figure 4. 
Figure 4. (A) - Photomicrograph of transverse histopathological evaluation of rabbit ventricular myocardium in a 40x objective in the SHAM group. Coloring: TM. (B) - Photomicrograph of transverse histopathological evaluation of rabbit ventricular myocardium in a 40x objective in the GT125 group. Coloring: TM. (C) - Photomicrograph of transverse histopathological evaluation of the rabbit ventricular myocardium in a 40x objective in the GT2000 group. Coloring: TM. (D) Representative graph of interstitial collagen volume density demonstrating the statistical difference between SHAM and GT125 and SHAM and GT2000 groups in doxorubicin-induced cardiotoxicity $(\mathrm{P}<0.05)$.

\section{Interstitial Collagen Volume Density}

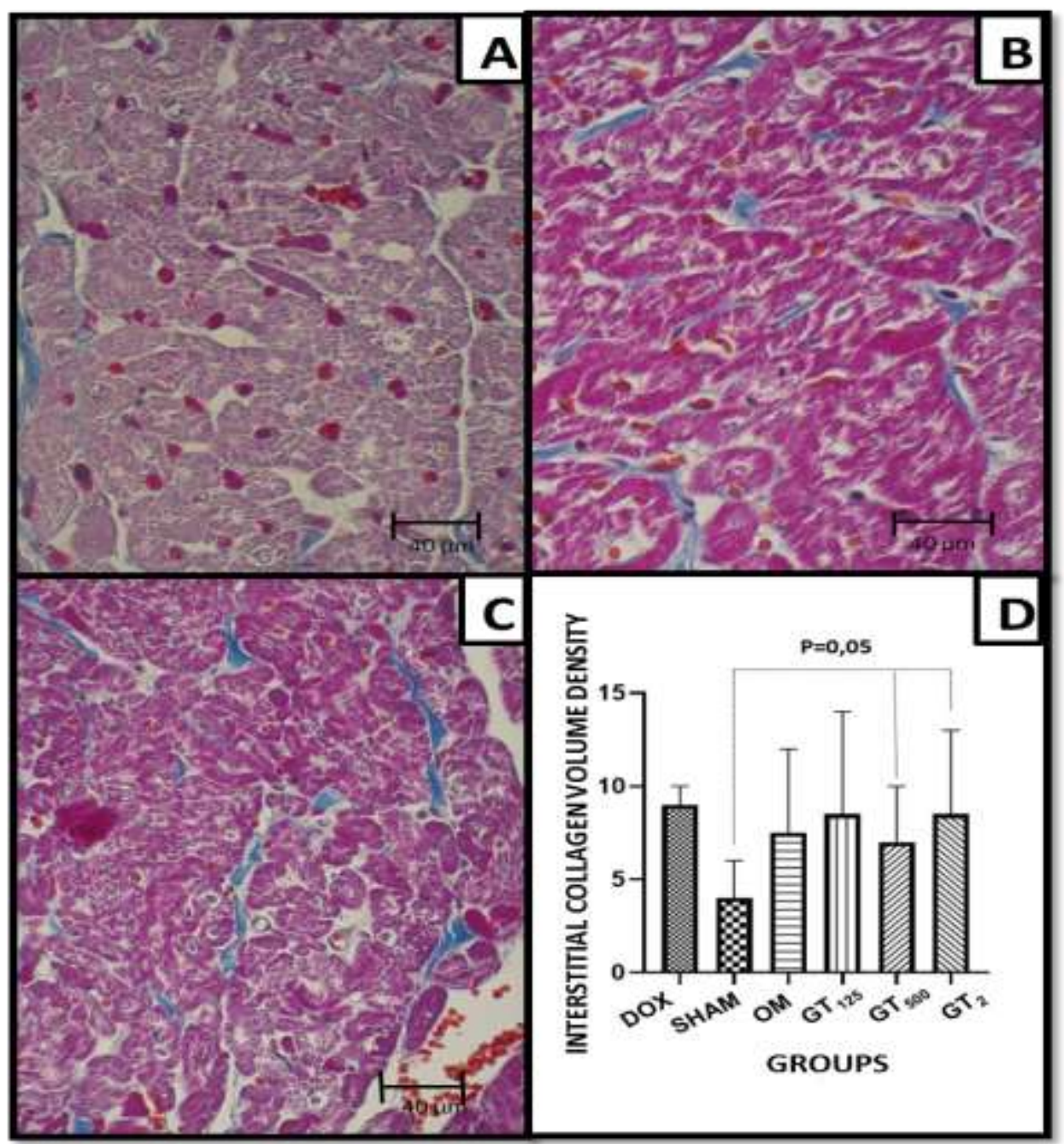

Source: Authors.

The morphometric evaluation applied to the number of vessels showed no statistical difference between the studied groups in Figure 5. 
Figure 5. (A) photomicrograph of transverse histopathological evaluation of the rabbit ventricular myocardium with dilated doxorubicin-induced cardiomyopathy in a 40x objective. Blood vessel (arrow) and vacuoles (arrow head) Coloring: HE. (B) Graph representing the morphometric evaluation of the number of vessels of rabbits with doxorubicin-induced dilated cardiomyopathy.

\section{Photomicrograph of transverse histopathological evaluation of the rabbit ventricular myocardium}

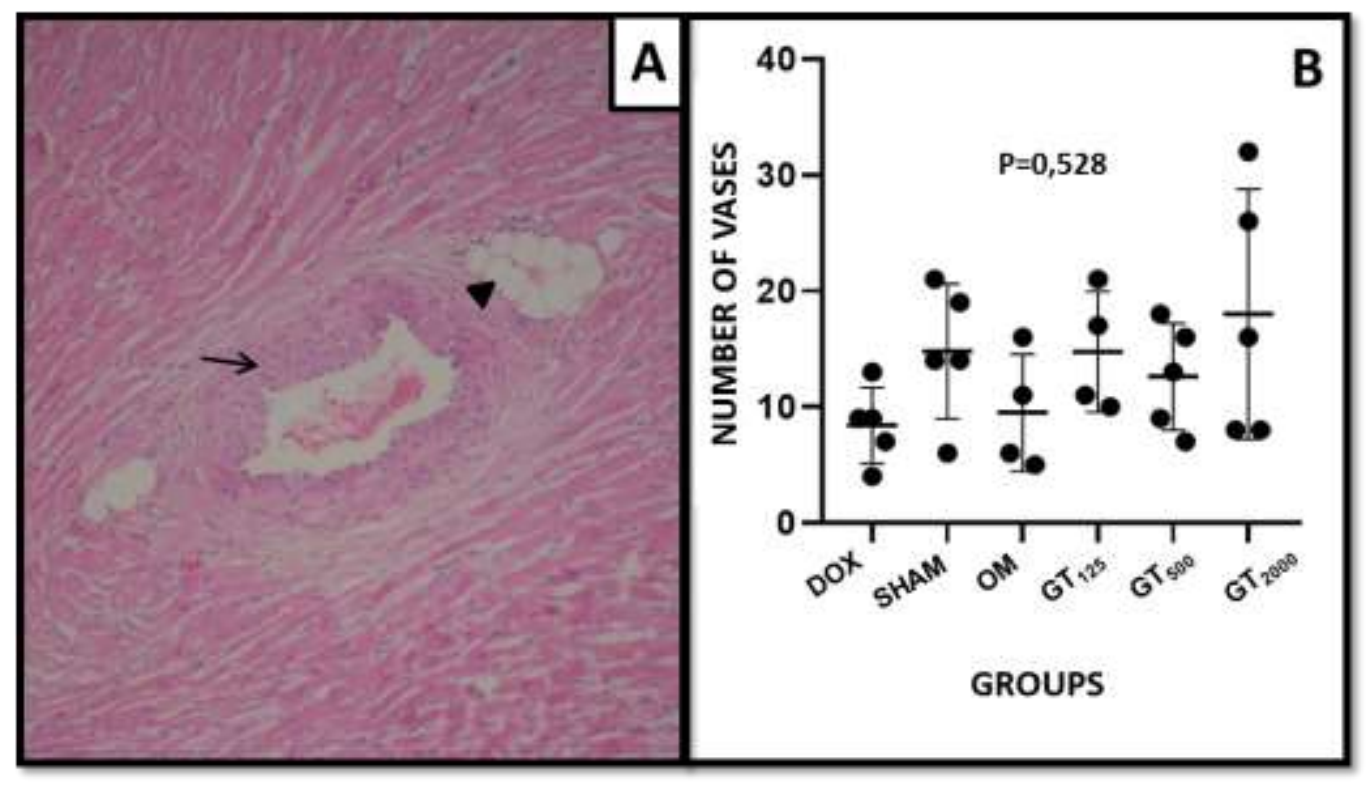

Source: Authors.

\section{Discussion}

The sensitivity of the cleft species as an experimental model in dilated cardiomyopathy secondary to the use of anthracyclines underlies the mortality rate obtained in the study. Mortality rates in studies conducted with chronic toxicity methodology are around 30-70\% (Talavera et al. 2015, El-Sayyad et al.2009).

However, the dose used in the $10 \mathrm{mg} / \mathrm{kg}$ single intravenous study was satisfactory for the acute induction of myocardial injury, with lower mortality than the previously described studies.

However, in an acute toxicity study in rats, no deaths were observed during the study period, emphasizing that the instituted dose was $20 \mathrm{mg} / \mathrm{kg}$ intraperitoneal (Polegato et al. 2015). This can be attributed to the higher tolerance of rodents to the drug under discussion since the evaluation period was the same in both studies (Talavera et al. 2015).

There are no plausible justifications for the animals that died in the same group, given the randomization of the study. Therefore, the toxic potential of anthracycline to other organs such as kidneys, liver and bone marrow may be considered and may justify the mortality of individuals (El-Sayyad et al. 2015). In addition to the use of chemotherapy, animals in the group that presented mortality were treated with a dose of $125 \mathrm{mg}$ of omega 3, and it could be extrapolated that this dose could potentiate the adverse effects of doxorubicin.

However, even with deaths during studies conducted over the years, rabbits are a reliable model for anthracycline cardiotoxicity in view of their similarity to cardiac electrophysiology in both humans and dogs and pigs (Pogwizd et al. 2008).

The cleft model is presented in a sound and consistent manner and is the standard for evaluation of cardioprotective drugs in a subsequent study for adjuvant therapy with doxorubin (Talavera et al. 2015). 
Based on previous studies, the evaluation of cardiovascular toxicity is commonly assessed by histopathological analysis (Gava et al. 2013). However, this type of essay is subject to subjectivity and limitation as it is a qualitative study. Therefore, it is worth emphasizing the importance of quantitative cardiotoxicity tests, such as stereological and morphometric studies, detailing and confirming results previously described (Rafati et al. 2017).

In the present evaluation there was no statistical difference in the density of cardiac fibers, contrary to what was described in a study conducted with rats evaluating doxorubin carditoxicity. However, changes in the evaluated parameter were evident only after days of chemotherapy administration, showing a late marker for myocardial toxicity (Klinnikova et al. 2016).

Considering the acute induction protocol of the present study, alterations such as hypertrophy demonstrated from the evaluation of the transverse area of cardiomyocytes can be justified by extrapolated histological evaluation data showing vacuolization and cellular degeneration in chronic toxicity studies (Gava et al. al. 2013). The increase in cell volume may be aimed at early alteration of late cell reorganization, early alterations of cell necrosis and apoptosis, findings of dose-dependent characteristic.

Myocardial fibrosis is a common final pathway of many cardiovascular diseases, with chronic inflammation and free radical release being the predisposing factors reported (Travers et al. 2016). Among the results observed in the study, the use of the omega $3500 \mathrm{mg} / \mathrm{kg}$ dose demonstrated the potential to reduce fibrotic effects secondary to anthracycline use, as described in humans after acute myocardial infarction (Heydari et al. 2016).

The short evaluation period of acute doxorubicin cardiotoxicity induction in rabbits was probably the primary factor to avoid neovascularization and alteration in the number of myocardial vessels. Scientific evidence is limited considering the poor description of these findings in the methodology applied in the present study.

\section{Conclusion}

Considering the results obtained in this study, it was possible to conclude that the dose of $500 \mathrm{mg} / \mathrm{kg}$ of omega 3 showed potential to minimize the fibrotic effects of doxorubicin use, requiring further studies. Furthermore, the use of $10 \mathrm{mg} /$ $\mathrm{kg}$ single dose doxorubicin can be used as a protocol for induction of acute dilated cardiomyopathy in an experimental model using rabbits.

In order to validate the results described, it is valid that future studies of cardiovascular functional assessment are detailed, such as echocardiographic, electrocardiographic and serum measurements of cardiac markers. Still, the evaluation of the use of omega should be used in patients using lower doses of the chemotherapeutic, evaluating whether the acute response is used in patients exposed.

\section{Acknowledgments}

This study was supported by grants of the Coordenação de Aperfeiçoamento de Pessoal de Nível Superior - Brasil (CAPES) - Finance Code 001.

\section{References}

Chen, Y., Liu, W., Li, W., \& Gao, C. (2010). Autologous bone marrow mesenchymal cell transplantation improves left ventricular function in a rabbit model of dilated cardiomyopathy. Experimental and molecular pathology, 88(2), 311-315.

Curry, H. L., Parkes, S. E., Powell, J. E., \& Mann, J. R. (2006). Caring for survivors of childhood cancers: the size of the problem. European Journal of Cancer, 42(4), 501-508. 
El-Sayyad, H. I., Ismail, M. F., Shalaby, F. M., Abou-El-Magd, R. F., Gaur, R. L., Fernando, A., \& Ouhtit, A. (2009). Histopathological effects of cisplatin, doxorubicin and 5-flurouracil (5-FU) on the liver of male albino rats. International journal of biological sciences, 5(5), 466.

Farraj, A. K., Hazari, M. S., \& Cascio, W. E. (2011). The utility of the small rodent electrocardiogram in toxicology. Toxicological sciences, 121(1), 11-30.

Gava, F. N., Zacché, E., Ortiz, E. M., Champion, T., Bandarra, M. B., Vasconcelos, R. O. \& Camacho, A. A. (2013). Doxorubicin induced dilated cardiomyopathy in a rabbit model: an update. Research in Veterinary Science, 94(1), 115-121.

Gewirtz, D. (1999). A critical evaluation of the mechanisms of action proposed for the antitumor effects of the anthracycline antibiotics adriamycin and daunorubicin. Biochemical pharmacology, 57(7), 727-741.

Hardman, W. E. (2004). (n-3) fatty acids and cancer therapy. The Journal of nutrition, 134(12), 3427S-3430S.

Heydari, B., Abdullah, S., Pottala, J. V., Shah, R., Abbasi, S., Mandry, D., ... \& Appelbaum, E. (2016). Effect of omega-3 acid ethyl esters on left ventricular remodeling after acute myocardial infarction: the OMEGA-REMODEL randomized clinical trial. Circulation, 134(5), 378-391.

Kero, A. E., Järvelä, L. S., Arola, M., Malila, N., Madanat-Harjuoja, L. M., Matomäki, J., \& Lähteenmäki, P. M. (2014). Cardiovascular morbidity in long-term survivors of early-onset cancer: a population-based study. International journal of cancer, 134(3), 664-673.

Klinnikova, M. G., Lushnikova, E. L., Koldysheva, E. V., Tolstikova, T. G., Sorokina, I. V., Yuzhik, E. I., \& Mzhelskaya, M. M. (2016). Cardiotoxic and Dyslipidemic Effects of Doxorubicin and Betulinic Acid Amide. Bulletin of experimental biology and medicine, 162(2), $277-282$.

Leaf, A., Kang, J. X., Xiao, Y. F., \& Billman, G. E. (2003). Clinical prevention of sudden cardiac death by n-3 polyunsaturated fatty acids and mechanism of prevention of arrhythmias by n-3 fish oils. Circulation, 107(21), 2646-2652.

Luu, A. Z., Chowdhury, B., Al-Omran, M., Teoh, H., Hess, D. A., \& Verma, S. (2018). Role of endothelium in doxorubicin-induced cardiomyopathy. JACC: Basic to Translational Science, 3(6), 861-870.

Moreno, C., Macías, Á., Prieto, Á., De La Cruz, A., González, T., \& Valenzuela, C. (2012). Effects of n- 3 polyunsaturated fatty acids on cardiac ion channels. Frontiers in physiology, 3, 245.

Murphy, R. A., Mourtzakis, M., Chu, Q. S., Baracos, V. E., Reiman, T., \& Mazurak, V. C. (2011). Supplementation with fish oil increases first-line chemotherapy efficacy in patients with advanced nonsmall cell lung cancer. Cancer, 117(16), 3774-3780.

Oeffinger, K. C., Mertens, A. C., Sklar, C. A., Kawashima, T., Hudson, M. M., Meadows, A. T. \& Schwartz, C. L. (2006). Chronic health conditions in adult survivors of childhood cancer. New England Journal of Medicine, 355(15), 1572-1582.

Olson, H. M., \& Capen, C. C. (1978). Chronic cardiotoxicity of doxorubicin (adriamycin) in the rat: morphologic and biochemical investigations. Toxicology and applied pharmacology, 44(3), 605-616.

Oshima, T., \& Fujiu, K. (2018). The Impact of Non-Cardiac Drugs on the Cardiac Repolarization Phase. International heart journal, 59(4), 677-679.

Pereira, L. M., Vianna, G. M., \& Mandarim-de-Lacerda, C. A. (1998). Morphology and stereology of the myocardium in hypertensive rats. Correlation with the time of nitric oxide synthesis inhibition. Arquivos brasileiros de cardiologia, 70(6), 397-402.

Pereira Neto, G. B., Andrade, J. N. B., Sousa, M. G., \& Camacho, A. A. (2006). Holter electrocardiography in dogs showing doxorubicin-induced dilated cardiomyopathy. Arquivo Brasileiro de Medicina Veterinária e Zootecnia, 58(6), 1037-1042.

Pogwizd, S. M., \& Bers, D. M. (2008). Rabbit models of heart disease. Drug Discovery Today: Disease Models, 5(3), 185-193.

Polegato, B. F., Minicucci, M. F., Azevedo, P. S., Carvalho, R. F., Chiuso-Minicucci, F., Pereira, E. J., ... \& Matsubara, L. S. (2015). Acute doxorubicininduced cardiotoxicity is associated with matrix metalloproteinase-2 alterations in rats. Cellular Physiology and Biochemistry, 35(5), $1924-1933$.

Preto, E., Lima, N. E., Simardi, L., Fonseca, F. L. A., Fragata Filho, A. A., \& Maifrino, L. B. M. (2015). Effect of mild aerobic training on the myocardium of mice with chronic Chagas disease. Biologics: targets \& therapy, $9,87$.

Rafati, A., Jafarinezhad, Z., Karbalay-Doust, S., Hosseini, L., \& Noorafshan, A. (2017). Microscopic evaluation of the ventricular tissue using stereological and Voronoi tessellation methods: Application on doxorubicin-induced cardiotoxicity in rats. Micron, 101, 1-7.

Saravanan, P., West, A. L., Bridgewater, B., Davidson, N. C., Calder, P. C., Dobrzynsky, H., ... \& O'Neill, S. C. (2016). Omega-3 fatty acids do not alter Pwave parameters in electrocardiogram or expression of atrial connexins in patients undergoing coronary artery bypass surgery. Ep Europace, 18(10), 15211527.

Szabuniewicz, M., Hightower, D., \& Kyzar, J. R. (1971). The electrocardiogram, vectorcardiogram and spatiocardiogram in the rabbit. Canadian Journal of Comparative Medicine, 35(2), 107.

Talavera, J., Giraldo, A., Fernández-Del-Palacio, M. J., García-Nicolás, O., Seva, J., Brooks, G., \& Moraleda, J. M. (2015). An upgrade on the rabbit model of anthracycline-induced cardiomyopathy: shorter protocol, reduced mortality, and higher incidence of overt dilated cardiomyopathy. BioMed research international, 2015.

Tilley, L. T. (1992). Essentials of canine and feline electrocardiography. 3. ed. Philadelphia: Lea \& Febiger;

Travers, J. G., Kamal, F. A., Robbins, J., Yutzey, K. E., \& Blaxall, B. C. (2016). Cardiac fibrosis: the fibroblast awakens. Circulation research, 118(6), 10211040 .

Viskin, S., Justo, D., Halkin, A., \& Zeltser, D. (2003). Long QT syndrome caused by noncardiac drugs. Progress in cardiovascular diseases, $45(5)$, $415-427$. 
Research, Society and Development, v. 10, n. 13, e60101320993, 2021

(CC BY 4.0) | ISSN 2525-3409 | DOI: http://dx.doi.org/10.33448/rsd-v10i13.20993

Voskoboinik, A., Prabhu, S., Sugumar, H., \& Kistler, P. M. (2018). Effect of dietary factors on cardiac rhythm. The American journal of cardiology, 122(7), $1265-1271$.

Xue, H., Ren, W., Denkinger, M., Schlotzer, E., \& Wischmeyer, P. E. (2016). Nutrition Modulation of Cardiotoxicity and Anticancer Efficacy Related to Doxorubicin Chemotherapy by Glutamine and $\omega-3$ Polyunsaturated Fatty Acids. Journal of Parenteral and Enteral Nutrition, 40(1), 52-66. 